\title{
PEMBINAAN PENINGKATAN MUTU PENDIDIKAN BIDANG OLIMPIADE SAINS BAGI GURU SD KOTA LANGSA PROVINSI ACEH
}

\author{
Fitra Muliani $^{1)}$, Dewi Noviati ${ }^{2)}$, Fajriani $^{3)}$ \\ ${ }^{1,2,3)}$ Fakultas Teknik Universitas Samudra \\ email: fitramuliani@unsam.ac.id
}

\begin{abstract}
Abstrak
Kegiatan pengabdian masyarakat bertujuan memberikan pengetahuan melalui pembinaan kepada guru - guru untuk pendalaman materi dan pelatihan soal olimpiade sains, sehingga membantu guru dalam menganalisis, mengarahkan, serta membimbing siswa yang akan mengikuti seleksi olimpiade ke tingkat kabupaten/kota, provinsi, dan nasional. Sasaran dalam kegiatan ini adalah guru pembimbing olimpiade matematika dan IPA dari beberapa sekolah SD Kota Langsa. Metode yang digunakan dalam kegiatan ini adalah metode pendekatan secara langsung, ceramah atau praktik. Metode pendekatan dilakukan dengan observasi permasalahan yang dihadapi oleh guru pembimbing. Metode ceramah dilakukan melalui sosialisasi dan pembinaan terkait materi olimpiade. Sedangkan metode praktik dilakukan melalui pelatihan dan pendalaman terhadap soal olimpiade sains. Hasil dari kegiatan ini adalah guru mampu menganalisis, mengarahkan, serta membimbing siswa - siswa yang akan mengikuti seleski olimpiade ke tingkat kabupaten/kota, provinsi, dan nasional sehingga dapat meningkatkan mutu pendidikan bidang olimpiade.
\end{abstract}

Kata Kunci : Industri kopra, mesin pengering, produktivitas.

\section{PENDAHULUAN}

Olimpiade Sains merupakan kompetensi bidang akademik bergengsi ditanah air, hal tersebut disebabkan banyaknya proses yang harus dilewati oleh peserta yaitu dimulai dari seleksi di tingkat sekolah, tingkat Kabupaten/kota, provinsi, nasional dan bahkan Internasional. Berdasarkan hal tersebut, olimpiade Sains Nasional adalah ajang kompetisi dalam bidang sains bagi para siswa pada jenjang SD, SMP, dan SMA di Indonesia. Siswa yang mengikuti Olimpiade Sains Nasional adalah siswa yang telah lolos seleksi tingkat kabupaten dan provinsi, dimana peserta adalah siswa-siswa terbaik dari provinsinya masing-masing. Untuk jenjang SD (Sekolah Dasar), hanya ada dua bidang yang diikutsertakan dalam olimpiade sains ditingkat kabupaten/Kota, nasional hingga ke tingkat Internasional yaitu Matematika dan IPA.

Paradigma bahwa matematika dan IPA adalah suatu ilmu pengetahuan yang sulit dan tidak menarik masih aktual hingga saat ini. Siswa sudah terbiasa dengan permasalahan - permasalahan sains yang sederhana dan mudah saja, sehingga berpengaruh terhadap minat siswa untuk mengikuti olimpiade sains dan menyebabkan siswa tidak mampu menemukan solusi persoalan matematika dan IPA yang rumit, khususnya soal - soal olimpiade. Hal tersebut menjadi perhatian khusus bagaimana guru perlu memberikan atau mengajar soal- soal yang serupa dengan soal olimpiade, sehingga siswa akan terbiasa dengan soal yang sulit dan memudahkan guru dalam membimbing siswa menyelesaikan soal olimpiade sains. Permasalahan terkait olimpiade matematika dan IPA masih menjadi sorotan, khususnya di Kota Langsa. Hal tersebut ditunjukkan pada hasil perolehan nilai serta sekolah yang menjadi juara olimpiade sains untuk SD tingkat wilayah Kota Langsa tahun 2018. Berdasarkan hasil perolehan nilai terlihat bahwa yang menjadi juara Olimpiade merupakan SD yang sama untuk bidang Matematika dan IPA, yaitu sebagai berikut

Tabel 1. Perolehan nilai olimpide Matematika SD Kota Langsa

\begin{tabular}{|c|l|l|c|c|}
\hline No & \multicolumn{1}{|c|}{ Nama } & Asal Sekolah & $\begin{array}{c}\text { Jumlah } \\
\text { Nilat }\end{array}$ & Rank \\
\hline I & Ye Zabir Aqsha & SDN 11 Langsa & 31 & 1 \\
\hline 2 & Muhammad Farhan & MIS THRPADU & 23 & 2 \\
\hline 3 & M. Nabil Dharma Putra & SDN 1 Langsa & 19 & 3 \\
\hline
\end{tabular}

Tabel 2. Perolehan nilai olimpide IPA SD Kota Langsa

\begin{tabular}{|c|l|c|c|c|}
\hline No & \multicolumn{1}{|c|}{ Nama } & Asal Sekolah & $\begin{array}{c}\text { Jumlah } \\
\text { Nilai }\end{array}$ & Rank \\
\hline 1 & Syafira Gadriella & SDN 5 Langsa & 60 & 1 \\
\hline 2 & Farel Alfaridzi & SDN 2 Langsa & 52.5 & 2 \\
\hline 3 & M. Nabil Dharma Putra & SDN 1 Langsa & 50 & 3 \\
\hline
\end{tabular}

Sumber : Rekapitulasi Hasil Perolehan Nilai Olimpiade IPA dan Matematika SD Tahun 2018 Kota Langsa 
Selain itu, berdasarkan hasil wawancara dengan salah satu kepala Sekolah yang menjadi juara olimpiade sains ditingkat Kota langsa untuk tiga tahun terakhir, sangat sulit bahkan hampir tidak ada peserta atau siswa yang lolos seleksi ditingkat Provinsi untuk lanjut ke tingkat Nasional. Hal tersebut di sebabkan oleh materi soal olimpiade tingkat provinsi sulit dijangkau atau diselesaikan oleh peserta, khususnya peserta yang mewakili kota Langsa. Permasalahan diatas juga dialami oleh guru yang membimbing dua bidang sains, yaitu kesulitan guru dalam menganalisis soal - soal olimpiade Sains belum teratasi, sehingga berdampak pada saat guru membimbing dan mengarahkan siswa dalam menyelesaikan permasalahan terkait. Soal olimpiade merupakan soal yang sulit utuk diselesaikan oleh siswa, dibutuhkan daya nalar dan kreativitas untuk menemukan solusi yang tepat. Jadi selain persiapan materi dan konsep dasar matematika dan IPA, siswa atau peserta dituntut untuk membiasakan diri berinovasi dan kreatif dengan teori - teori bidang sains yang telah dikuasainya.

Berdasarkan hal tersebut, perlu adanya pembinaan kepada guru - guru untuk pendalaman materi dan pelatihan soal olimpiade sains, dengan adanya pengabdian masyarakat ini diharapkan mampu membantu guru dalam menganalisis, mengarahkan, serta membimbing siswa yang akan mengikuti seleski olimpiade ke tingkat kabupaten/kota, provinsi, dan nasional.

\subsection{Permasalahan Prioritas Mitra}

Berdasarkan analisis situasi yang berkembang saat ini, permasalahan utama yang dihadapi mitra/ guru yaitu:

1) Kesulitan guru menganalisis materi yang terkait dengan soal olimpiade, sehingga berpengaruh dalam membimbing dan mengarahkan siswa yaang akan mengikuti olimpiade.

2) kepedulian terhadap perkembangan serta prestasi sekolah - sekolah dikota langsa untuk bisa menjadi juara dan berpatisipasi pada ajang olimpiade tingkat provinsi bahkan Nasional.

3) Terdapat beberapa Guru pembimbing olimpiade disekolah masih belum memiliki keterampilan dalam menganalisis dan menyelesaikan soal olimpiade, baik soal olimpiade tingkat kabupaten/ kota, provinsi bahkan nasional

Berdasarkan permasalahan tersebut, maka pelaksanaan kegiatan pengabdian masyarakat ini adalah upaya untuk memberikan solusi kepada guru dengan memberikan pelatihan serta pembinaan melalui pendalaman materi dan membahas serta melihat tingkat kesulitan materi soal olimpiade.

\subsection{Justifikasi Solusi Atas Permasalahan Mitra}

Berdasarkan analisis situasi dari permasalahan yang dihadapi, maka solusi yang dapat diusulkan untuk menyelesaikan permasalahan adalah sebagai berikut:

1. Pembinaan serta pendalaman materi soal olimpiade sains.

2. Pelatihan dan pembahasan soal- soal olimpiade yang sulit, untuk meningkatkan keterampilan guru dalam mengalisa dan meyelesaikan permasalahan soal olimpiade

3. Guru ikut Berpartisipasi dalam ajang olimpiade tingkat provinsi dan Nasional, yaitu dengan mengirimkan siswa berprestasi dan mampu dibidang sains yang telah dibimbing

\subsection{Solusi Yang Ditawarkan}

Berdasarkan permasalahan prioritas yang dihadapi mitra dan hasil dari kesepakatan antara pengusul dengan kedua mitra, maka diperoleh solusi antara lain sebagai berikut.

a. Mensosialisasikan kepada seluruh guru pembimbing olimpiade Kota Langsa untuk mengikuti pembinaan dan pelatihan materi soalsoal olimpiade sains dibawah koordinasi kelompok kerja Guru (KKG) Gugus 1 handayani (mitra 1)

b. Membuat pembinaan materi dan pelatihan soal soal olimpiade terhadap guru pembimbing olimpiade sains kota Langsa pada SD N 1 Langsa ( mitra 1)

c. Menyiapkan sarana untuk dilaksanakannnya pembinaan dan pelatihan terhadap guru pembimbing olimpiade sains kota Langsa pada SD N 1 Langsa ( mitra 2) 


\section{METODE KEGIATAN}

Adapun metode pelaksanaan kegiatan pengabdian ini menggunakan metode pendekatan secara langsung, ceramah dan praktik. Adapun tahapan yang dilakukan dalam pelaksanaan kegiatan ini meliputi:

\section{a. Tahapan Persiapan}

Pada tahap persiapan atau tahap awal, tim pelaksana kegiatan pengabdian kepada Masyarakat (PKM) melakukan observasi terhadap kelompok kerja Guru Kota Langsa, observasi dilakukan untuk mengetahui masalah yang dihadapi oleh guru, khususnya guru pembimbing olimpiade Matematika dan IPA. Kemudian tim melakukan survei tempat yang dapat digunakan untuk dilakukannya kegiatan PKM ini yaitu sekolah Dasar Nageri 1 Langsa. Setelah diketahui permasalahan mitra kemudian disusun suatu solusi untuk dapat diterapkan pada tahapan pelaksanaan

\section{b. Pelaksanaan}

Tahapan kedua atau pelaksanaan kegiatan terbagi menjadi dua bagian, yaitu :

\section{1) Sosialisasi}

Pada tahap ini, tim bersama ketua KKG melakukan sosialisasi mengenai kegiatan yang akan dilaksanakan yaitu pembinaan dan pendalaman materi soal olimpiade sains, serta mengundang guru pembimbing olimpiade untuk dapat mengikuti kegiatan tersebut yang akan dilaksanakan di Sekolah Dasar Negeri 1 Langsa.

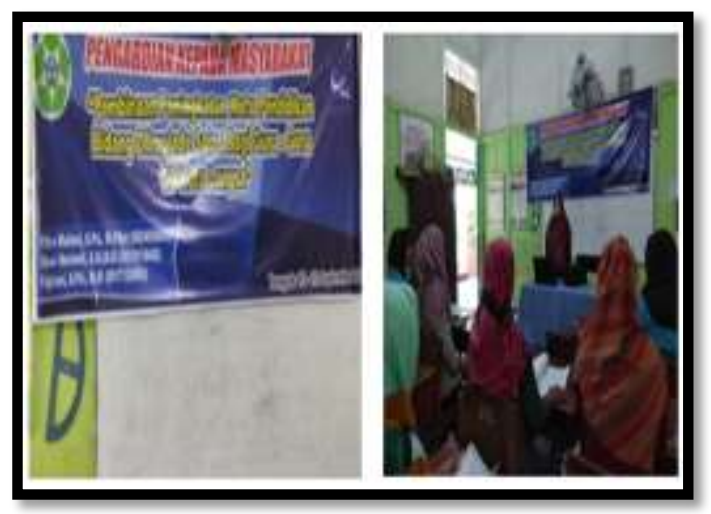

Gambar 1.

Sosialisasi program kegiatan pengabdian Masyarakat

\section{2) Praktek}

Pada tahapan ini, awalnya dilakukan pengayaan materi olimpiade sains dan materi yang sulit terlebih dahulu, kemudian instruktur melakukan pembinaan dan pendalaman terhadap soal olimpiade sains. Kemudian dilanjutkan dengan latihan soal - soal olimpiade tingkat kabupaten/ Kota, Provinsi dan Nasional.

Adapun kriteria penilaian meliputi pemahaman guru terhadap materi dan mampu menyelesaikan permasalahan soal yang berhubungan dengan soal olimpiade diberikan selama proses kegiatan berlangsung.

\section{c. Evaluasi Kegiatan}

Tahap ke-tiga yaitu melihat tingkat keberhasilan pelaksanan pengabdian kepada masyarakat yang diusulkan ini akan dievaluasi selama pelaksanaan berjalan. Evaluasi awal dilakukan oleh tim pelaksana dalam dua hal kegiatan, yaitu:

1. Kegiatan inti merupakan kegiatan yang dilakukan saat diberikannya pembinaan, pendalaman dan

2. Diluar kegiatan inti, yaitu kegiatan pendampingan yang dilakukan setelah tim pelaksana melaksanakan kegiatan pengabdian kepada masyarakat. Hal ini dilakukan untuk memastikan bahwa guru-guru telah mengerti dan terampil dalam menyelesaikan soal- soal olimpiade sains sehingga dengan mudah membimbing siswa yang akan mengikuti kompetisi olimpiade.

Berdasarkan pada analisis situasi, kondisi permasalahan yang dihadapi mitra dan solusi yang telah disepakati bersama, maka metode pendekatan yang ditawarkan oleh tim PKM untuk menyelesaikan persoalan mitra, yaitu disajikan pada gambar berikut: 


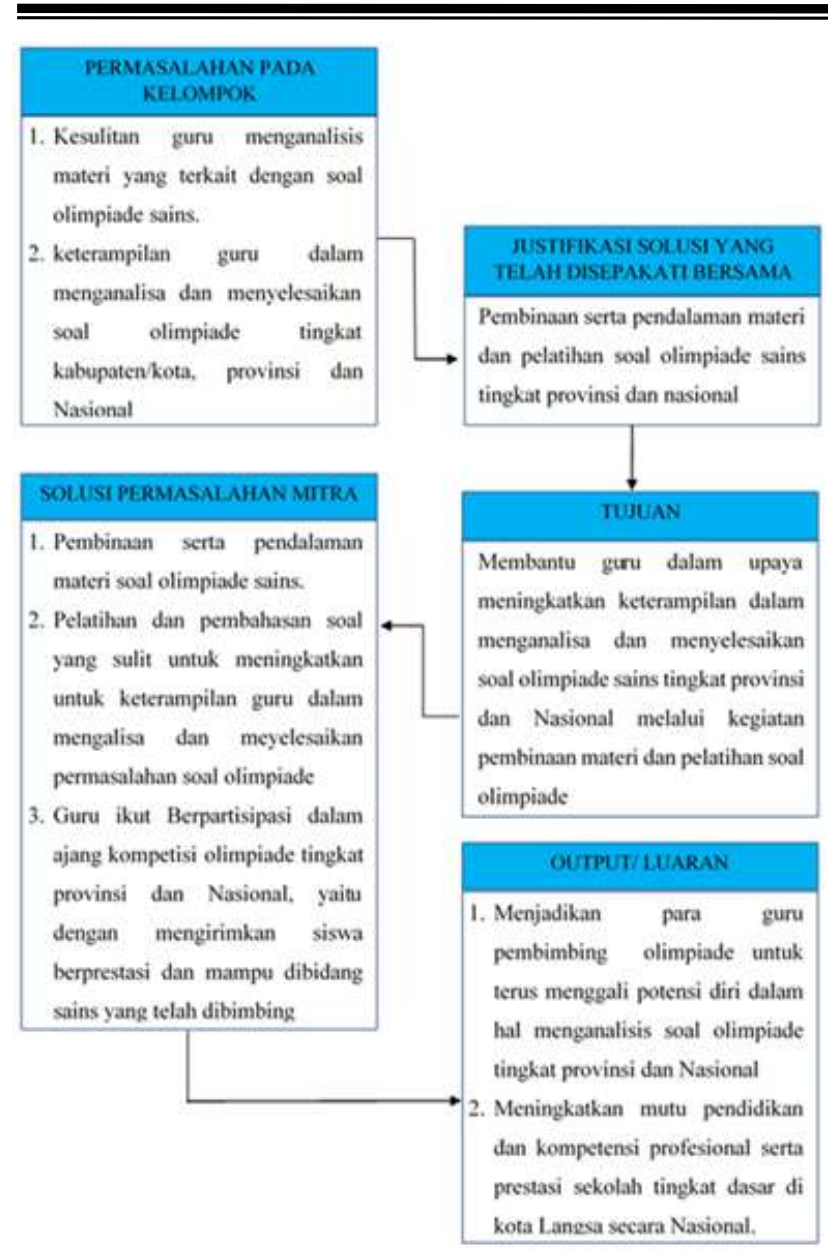

Gambar 2

Diagram kerangka konsep

penyelesaian masalah

Adapun indikator keberhasilan dari kegiatan program PKM ini antara lain:

a. Guru mampu memahami materi terkait soal olimpiade.

b. Guru mampu menganalisis dan terampil dalam menyelesaikan soal olimpiade sains.

c. Dapat meningkatkan mutu pendidikan bidang olimpiade sains Kota Langsa.

Selain itu mitra berpartisipasi secara aktif dalam setiap kegiatan, dimulai dari tahap awal saat survei tempat dan permasalahan yang sedang dihadapi saat ini. Tim pengusul berdiskusi dengan mitra I dan mitra II yaitu ketua kelompok kerja guru (KKG) dan kepala sekolah SDN 1 kota langsa terkait permasalah yang ada yaitu kesulitan guru dalam menganalisis dan menyelesaikan soal olimpiade tingkat kabupaten/kota, Provinsi, dan Nasional. Kemudian mitra I berperan aktif sebagai koordianator untuk mensosialisasi program kegiatan kepada anggota KKG gugus 1 Handayani kota langsa dan mitra II menyediakan sarana yaitu tempat dilaksanakannya kegiatan PKM ini

\section{HASIL DAN PEMBAHASAN}

Untuk kegiatan yang dimulai dari sosialisasi, pengayaan materi sampai dengan pelatihan berjalan dengan baik, hal ini dapat dilihat dari partisipasi guru yang hadir dalam kegiatan tersebut yang juga dihadiri oleh kepala sekolah SD Negeri 1 Langsa dan ketua serta sekretaris KKG gugus handayani Kota Langsa. Kegiatan ini dimulai dengan pembukaan dan sambutan dari ketua tim Pengabdian masyarakat, kemudian dilanjutkan sambutan dari Kepala Sekolah dan ketua KKG kota Langsa, selanjutnya dilaksanakan pengayaan materi yang merupakan materi olimpiade sains, baik IPA maupun Matematika. Setelah dilakukan pengayaan materi, kemudian dilanjutkan dengan pelatihan serta pemantapan soal olimpiade sains tingkat sekolah dasar oleh tim PKM.

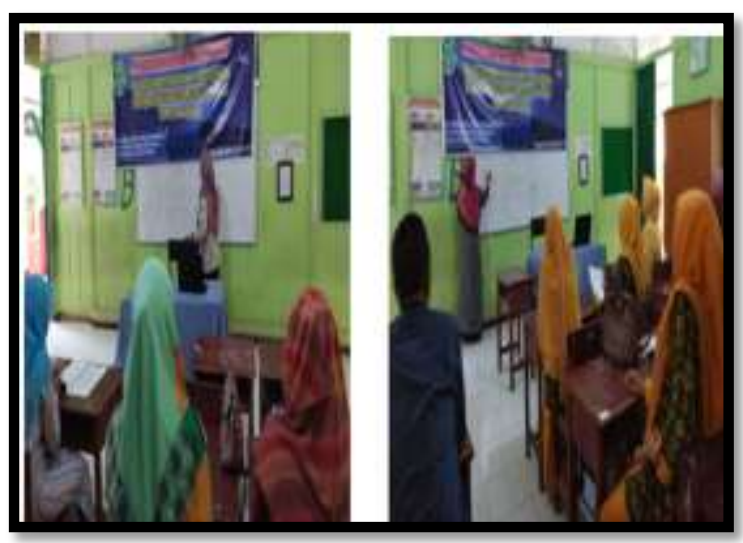

Gambar 3.

Pengayan materi dan pelatihan soal olimpiade sains

Dalam kegiatan tersebut guru dan tim PKM saling sharing terhadap kesulitan yang dihadapi oleh guru pendamping dalam membimbing siswa yang mengikuti olimpiade, yaitu bagaimana membahas terkait materi yang sulit dan bagaimana cara mengajarkan kepada siswa agar siswa mudah dalam mengekplorasi kemampuan untuk menjawab soal olimpiade, sebagai bahan penunjang, para peserta diberikan modul sehingga dapat memudahkan mereka dalam mengikuti pelatihan, selanjutnya guru - guru pembimbing diminta untuk menyelesaikan 
beberapa persoalan olimpiade Matematika dan IPA yang diberikan sebagai latihan untuk selanjutnya dapat dipraktikkan di kelas.

Hasil yang diperoleh dari kegiatan pengabdian masyarakat ini adalah $80 \%$ sosialisasi dan pelatihan berjalan sangat baik dan $20 \%$ untuk pendampingan. Untuk tingkat partisipasi juga sangat bagus. Hal tersebut terlihat dari antusiasme peserta PKM yang ditunjukkan dengan adanya minat dan semangat dari para peserta yang hadir pada kegiatan ini, selain itu para peserta dan tim PKM juga bekerja sama dan saling sharing terhadap permasalah yang dihadapi guru ketika membimbing olimpiade baik bidang IPA atau Matematika. Para peserta juga sangat mengharapkan agar tim PKM di masa mendatang dapat mengadakan pelatihan yang menunjang prestasi sekolah, sehingga dapat meningkatan mutu pendidikan khususnya di daerah.

\section{KESIMPULAN}

Kesimpulan yang diperoleh dari pelaksanaan program pengabdian masyarakat "Pembinaan Peningkatan Mutu Pendidikan Bidang Olimpiade Sains Bagi Guru - Guru SD Kota Langsa" Adalah :

1. Meningkatkan kompetensi profesional guru matematika dan IPA, khususnya pada bidang olimpiade sains
2. Tingkat partisipasi mitra dan peserta yang tinggi terhadap program pengabdian masyarakat Pembinaan Peningkatan Mutu Pendidikan Bidang Olimpiade Sains Bagi Guru - Guru SD Kota Langsa memberikan dampak yang positif terhadap bagi pelaksanaan program kegiatan pengabdian (PKM)

3. Pelaksanaan program pengabdian ini diharapkan mampu meningkatkan mutu pendidikan khususnya pada bidang olimpiade sains Matematika dan IPA

4. Kegiatan PKM ini dapat meningkatkan profesional guru dalam membimbing siswa, serta dapat menunjang dalam meningkatkan prestasi sekolah khusunya bidang olimpiade sains.

\section{Ucapan Terima Kasih}

Tim Pengabdian Kepada Masyarakat mengucapkan terima kasih kepada LPPM yang telah membiayai kegiatan ini melalui anggaran DIPA Universitas Samudra, Ketua, Sekretaris KKG gugus handayani Kota Langsa dan guru - guru pembimbing olimpiade sains SD di kota Langsa.

\section{REFERENSI}

Prasodjo Budi \& Kristina Linda. Menyongsong Olimpiade Matematika Tingkat Nasional dan Internasional SD/MI. Surabaya: JP Books

Mulyasa, E. 2007. Standar Kompetensi dan Sertifikasi Guru. Bandung; PT. Remaja Rosda Karya. 